\title{
Growth of Penaeus aztecus Ives, 1891 and Penaeus duorarum Burkenroad, 1931 in a hypersaline lagoon: relationships with environmental conditions and body size
}

\author{
ROBERTO PEREZ-CASTANEDA, JESUS GENARO SANCHEZ-MARTINEZ, \\ MARIA DE LA LUZVAZQUEZ-SAUCEDA, JAIME LUIS RABAGO-CASTRO, \\ JORGE ALBERTO LOPEZ-ROCHA*, FLAVIANO BENAVIDES-GONZALEZ \\ AND ZEFERINO BLANCO-MARTINEZ \\ Faculty of Veterinary Medicine and Zootechnics, Autonomous University of Tamaulipas, Cd. Victoria, Tamaulipas \\ Mexico \\ "Multidisciplinary Teaching and Research Unit, Science Faculty, National Autonomous University of Mexico \\ Sisal Yucatan, Mexico \\ e-mail: zblanco@docentes.uat.edu.mx
}

\section{ABSTRACT}

Growth rates of the brown shrimp Penaeus aztecus Ives, 1891 and pink shrimp Penaeus duorarum Burkenroad, 1931 were estimated using length-frequency data in the hypersaline coastal lagoon, Laguna Madre of Tamaulipas, Mexico. The influence of environmental variables (salinity and temperature) and shrimp body size on the growth of both penaeid species were also evaluated. Shrimps were collected monthly from two fishing zones located at the central part of the lagoon throughout one year. A total of 4458 shrimps were analysed (69.3\% P. aztecus and 30.7\% P. duorarum) with total lengths (TL) ranging from 50.9 to $131.4 \mathrm{~mm}$ in $P$. aztecus and 59.7 to $134.5 \mathrm{~mm}$ in $P$. duorarum. Mean growth rate $( \pm \mathrm{SD})$ of P. duorarum ( $3.10 \pm 1.78 \mathrm{~mm}$ TL per week) was slightly higher than that of $P$. aztecus ( $2.71 \pm 1.37 \mathrm{~mm}$ TL per week); however, the interspecific difference was not significant ( $p>0.05$ ). Growth rates for both the penaeid shrimp species increased as water temperature increased. Additionally, a negative relationship between the growth rate and body length of shrimp was also detected suggesting that the positive effect of water temperature on the increase in shrimp length may be size dependent.

Keywords: Coastal lagoon, Laguna Madre, Penaeid shrimp, Penaeus aztecus, Penaeus duorarum

\section{Introduction}

Penaeid shrimps (Family Penaeidae) represent the most valuable fishery export in several tropical developing countries (Gillett, 2008). The shrimp fishery in the Gulf of Mexico is one of the most important fisheries of the Western Central Atlantic Ocean (Neal and Maris, 1985; FAO, 2015). Commercial shrimps in the Gulf of Mexico are dominated by the brown shrimp Penaeus aztecus, the pink shrimp Penaeus duorarum and the white shrimp Litopenaeus setiferus. Xiphopenaeus kroyeri (Atlantic seabob) and Sicyonia brevirostris (brown rock shrimp) are also present, mainly in the southern Mexican coast (INP, 2006).

Juveniles of penaeid shrimps utilise coastal lagoons and estuaries as nursery areas for several months, before migrating to the sea where they reach adult stage (Dall et al., 1990). In these coastal ecosystems, juvenile shrimps are usually exploited using various types of artisanal fishing gears, whereas adult shrimps are exploited by industrial fleets at sea, which is characteristic of sequential fisheries like the shrimp fishery (Garcia and Le Reste, 1981; Gillett, 2008). Despite the relevance of coastal lagoons for the life cycle of penaeid shrimps and its fishery, there are only very few studies on shrimp population dynamics in these ecosystems.

Environmental conditions are important in determining the spatial and temporal fluctuations of shrimp populations within coastal lagoons and estuaries (Adnan et al., 2002; Perez-Castaneda and Defeo, 2004; Ruas et al., 2014; Blanco-Martinez and Perez-Castaneda, 2017; Mace and Rozas, 2017). Moreover, population parameters such as growth, mortality or migration may also be affected by biotic and abiotic factors, as reported for some penaeid shrimp species (Benfield et al., 1990; Haywood and Staples, 1993; O’Brien, 1994; RamirezRodriguez and Arreguin-Sanchez, 2000; Perez-Castaneda and Defeo, 2005; Rozas and Minello, 2011). 
Growth of certain penaeid shrimps in marine waters has been described by a curvilinear function of body length over time, e.g., fitting the von Bertalanffy model (Ramirez-Rodriguez and Arreguin-Sanchez, 2000); however, juvenile shrimp in coastal lagoons have a rapid growth, which can be described by a linear function. In fact, the von Bertalanffy model is practically linear over the size range of juvenile shrimps (Dall et al., 1990; Perez-Castaneda and Defeo, 2003). Studies on penaeid shrimp population dynamics have mainly focused on the marine phase of its life cycle, perhaps due in part to the economic relevance of industrial shrimp fisheries around the world which target adult shrimp at sea (Gillett, 2008). Conversely, studies on the population parameters of juvenile shrimps exploited by artisanal fishermen in coastal lagoons are scarce. It is clear that the knowledge of the biological and ecological features of penaeid shrimps during its juvenile stage in coastal lagoons would be of relevance in the assessment and management of this important fishery resource.

The Laguna Madre of Tamaulipas, located in the Gulf of Mexico, is the second biggest coastal lagoon in Mexico and supports the most important artisanal shrimp fishery in this country, in terms of volume and number of fishermen. In fact, shrimp capture in the Laguna Madre of Tamaulipas represents about $24 \%$ of the total shrimp catch in the Exclusive Economic Zone in the Gulf of Mexico (INP, 2006; CONAPESCA, 2013). The population structure of penaeids from the artisanal shrimp fishery in this important lagoon has been previously documented indicating the dominance of $P$. aztecus and P. duorarum (Perez-Castaneda et al., 2012). However, for these exploited shrimp species, the estimate of population parameters, such as growth, has not been evaluated. The aim of the present study was to assess the growth rates of $P$. aztecus and $P$. duorarum in Laguna Madre and their relationship with environmental variables, as well as their possible variations in relation to shrimp size.

\section{Materials and methods}

Study area

The Laguna Madre of Tamaulipas is a $200 \mathrm{~km}$ long subtropical coastal lagoon located in the Gulf of Mexico $\left(23^{\circ} 50^{\prime}-25^{\circ} 30^{\prime} \mathrm{N} ; 97^{\circ} 15-97^{\circ} 45^{\prime} \mathrm{W}\right)$. It has an area of approximately $200 \mathrm{~km}^{2}$ and a maximum depth of about $3 \mathrm{~m}$. The lagoon is separated from the sea by a long and narrow barrier island which extends along most of the lagoon in a north-south direction. Four permanent tidal inlets (200-400 m width) breach this barrier island, providing some water exchange between the lagoon and the Gulf of Mexico (Fig. 1). This characteristic and the insignificant river discharges have made the Laguna Madre
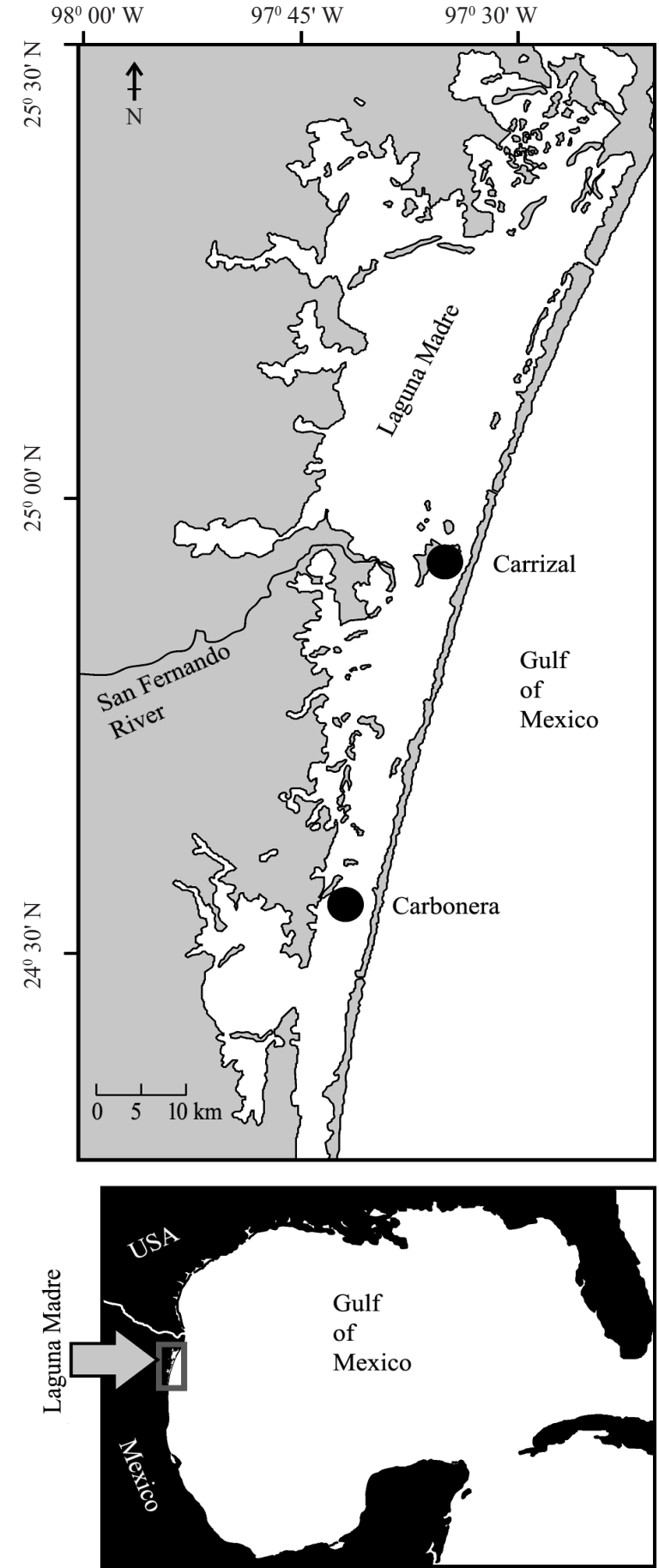

Fig. 1. Location of sampling sites $(\bullet)$, at two fishing zones (Carrizal and Carbonera) in Laguna Madre, Tamaulipas, Mexico

of Tamaulipas a hypersaline lagoon, which together with the Laguna Madre of Texas (USA) comprise the greatest hypersaline lagoon system in North America (Tunnel and Judd, 2002). 


\section{Sample collection and analysis}

Sampling was carried out monthly (October 2007 to August 2008), during the night, at two important fishing zones (Carrizal and Carbonera) located in the central part of the lagoon. Shrimp samples were obtained from artisanal fishing gears known as "charangas", which are passive fishing gears used by local fishermen. This fishing gear is a V-shaped trap (54 m mouth; $56 \mathrm{~m}$ long) made with stakes supporting a net of $3.81 \mathrm{~cm}$ mesh size, with a rectangular enclosure at the end tip where shrimps are retained and harvested with a circular dip net $(2.5 \mathrm{~m}$ dia, $3.18 \mathrm{~cm}$ mesh size). Two charangas per fishing zone (i.e., two sites per zone) were sampled at each sampling date. At each site, water salinity and temperature were also measured using a refractometer and a thermometer respectively. Shrimps were stored in polypropylene bottles and kept in ice immediately after capture. Subsequently, they were transported to the laboratory where they were fixed in $70 \%$ ethyl alcohol. In the laboratory; specimens were measured for total length (TL) to the nearest $0.1 \mathrm{~mm}$ with a caliper and separated by species according to their morphologic characteristics as outlined by Perez-Farfante (1970; 1988).

\section{Data analysis}

Modal progression analysis was carried out to estimate growth rates of $P$. aztecus and $P$. duorarum. In order to reduce biases caused by possible migration of shrimp between zones, catches from both fishing zones were pooled to analyse monthly length-frequency data. Length frequency distributions (LFD) were constructed, in intervals of $3 \mathrm{~mm}$ TL for each shrimp species, and plotted sequentially for each sampling date.

To estimate growth rates, normal components (cohorts) in each LFD were identified and separated using

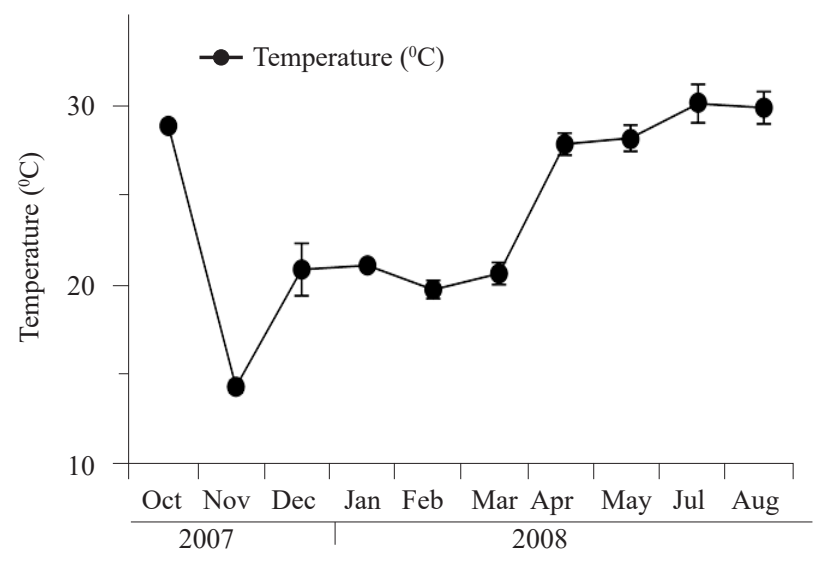

(a) the NORMSEP routine (Gayanilo and Pauly, 1997); mean total length (TL) and standard deviation (SD) for each identified cohort were calculated through this routine. Starting values, number of normal components (cohorts) and their respective mean lengths, required by NORMSEP were previously estimated following Bhattacharya (1967) method. A separation index (SI) higher than 2.0 was used as a criterion to separate contiguous normal components in each LFD (Gayanilo and Pauly, 1997). Identified cohorts were followed through time by linking the mean TL of consecutive sampling dates. Afterwards, growth rates (mm TL per week) were calculated by increments in mean TL between consecutive sampling dates. Estimates of growth were based on cohorts ranging from 57 to $100 \mathrm{~mm}$ TL in P. aztecus and 63 to $117 \mathrm{~mm}$ TL in P. duorarum.

Student's t-test was used to evaluate differences in growth rates between both species, after verifying the normality and homogeneity of variances. Growth rates were related with water temperature, salinity, and shrimp body size. These analyses were performed separately for each species using linear or non-linear functions depending on the nature of the relationship. In this regard, mean values of temperature and salinity were calculated for the same period for which growth rates were estimated. On the other hand, the relationship between body size and growth of shrimp was performed relating the initial mean TL of each cohort with its corresponding growth rate.

\section{Results and discussion}

Water temperature ranged from 14.0 to $31.6^{\circ} \mathrm{C}$ with a mean value $( \pm \mathrm{SD})$ of $24.2 \pm 5.4^{\circ} \mathrm{C}$. The highest mean temperature was observed in July $\left(30.3 \pm 1.1^{\circ} \mathrm{C}\right)$ and the lowest in November $\left(14.3 \pm 0.4^{\circ} \mathrm{C}\right)$. Salinity ranged from 26 to $42 \%$ with an average of $35.2 \pm 3.7 \%$; the highest salinity was registered in April $(39.8 \pm 1.7 \%)$ and the lowest in July $(28.5 \pm 3.0 \%$ \%) (Fig. 2).

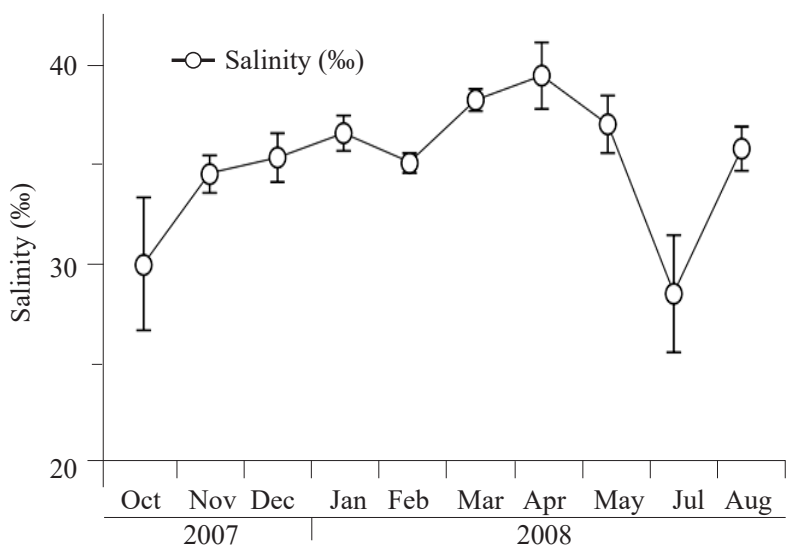

(b)

Fig. 2. Mean $( \pm \mathrm{SD})$ water temperature and salinity in Laguna Madre during the study period 
A total of 4458 shrimps were analysed; of which 3090 corresponded to brown shrimp (P. aztecus) and 1368 to pink shrimp ( $P$. duorarum). Most individuals were predominantly subadults followed by juveniles. Only three adult individuals from each shrimp species were caught throughout the study period. Total length of $P$. aztecus ranged from 50.9 to $131.4 \mathrm{~mm}$ TL and that of $P$. duorarum from 59.7 to $134.5 \mathrm{~mm}$ TL. According to the life cycle of penaeids (Dall et al., 1990), the presence of adult shrimps is uncommon in coastal lagoons; however, under high salinity conditions shrimps stay in coastal lagoons until an unusually advanced age (Garcia and Le Reste, 1981). This explain the presence of large individuals (up to $134.5 \mathrm{~mm}$ TL) in Laguna Madre which is characterised by salinities greater than seawater.

Growth rates

Estimated growth rates ranged from 1.37 to $4.82 \mathrm{~mm}$ TL per week in P. aztecus and from 1.28 to $6.90 \mathrm{~mm} \mathrm{TL}$ per week in $P$. duorarum. Mean growth rate in $P$. duorarum $(3.10 \pm 1.78 \mathrm{~mm}$ TL per week) was slightly higher than in $P$. aztecus $(2.71 \pm 1.37 \mathrm{~mm}$ TL per week); however, no significant differences $(\mathrm{p}>0.05)$ between species were detected (Fig. 3).

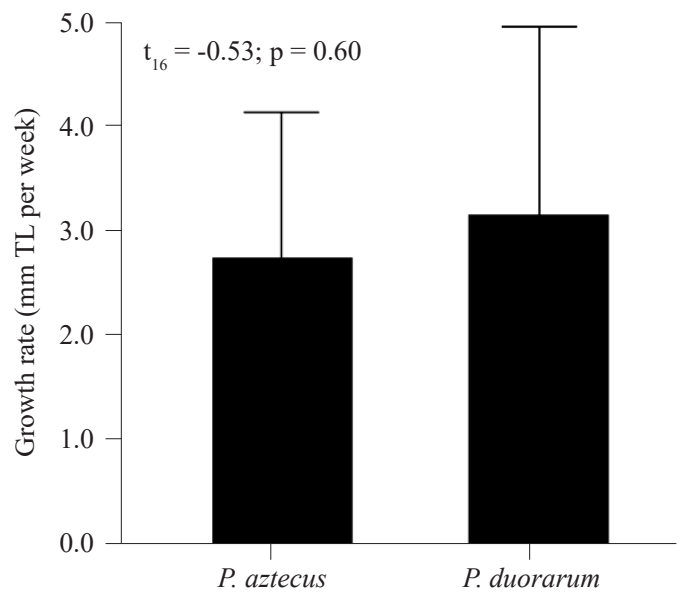

Fig. 3. Growth rates (mean $\pm \mathrm{SD}$ ) estimated for $P$. aztecus and $P$. duorarum caught in Laguna Madre

Growth rates of $P$. aztecus and $P$. duorarum in Laguna Madre were within the range estimated for juvenile individuals of these penaeid species from submerged aquatic vegetation habitats in other coastal lagoons from the Gulf of Mexico. For instance, growth rates reported for P. aztecus in Celestun Lagoon (a tropical coastal lagoon from the Yucatan Peninsula) were 0.49 to $0.94 \mathrm{CL}$ per week (CL: carapace length) which equals to 2.18 to $4.18 \mathrm{~mm}$ TL per week (considering $\mathrm{TL}=4.45$ $\mathrm{x}$ CL) and for $P$. duorarum were 0.46 to $1.55 \mathrm{CL}$ per week which corresponds to 2.05 to $6.9 \mathrm{~mm}$ TL per week (Perez-Castaneda and Defeo, 2005). Similarly, juveniles of Penaeus brasiliensis and Penaeus notialis in Celestun grew up to 1.24 and $1.52 \mathrm{~mm}$ CL per week, respectively (equivalent to 5.52 and $6.76 \mathrm{~mm}$ TL per week). The highest growth rates for $P$. aztecus and $P$. duorarum in Laguna Madre were lower than maximum growth rates observed in most penaeids from Celestun and this result might be related to differences in water temperature between the two coastal lagoons. Temperatures registered in Celestun Lagoon ranged from 23.2 to $30.5^{\circ} \mathrm{C}$ (Perez-Castaneda and Defeo, 2005) while those in the Laguna Madre ranged from 14.0 to $31.6^{\circ} \mathrm{C}$ making the minimum temperature in Laguna Madre almost $10^{\circ} \mathrm{C}$ lower than that observed in Celestun, which could explain the lower growth rates estimated for both penaeid shrimp species in the present study. Another possible cause could be the fact that the growth rates in Celestun were calculated from smaller individuals ( 25 to $30 \mathrm{~mm}$ TL smaller) which could exhibit a faster growth than larger shrimps analysed in Laguna Madre.

Growth rates estimates for $P$. duorarum in the present study were relatively lower than those reported in Terminos Lagoon (4.06 to $7.91 \mathrm{~mm}$ TL per week) by Alvarez et al. (1987). However, shrimps analysed in Terminos Lagoon were much smaller (post-larvae and early juveniles) than in this study. It has been documented that growth rates in penaeids are size-dependent, with smaller shrimps experiencing faster growth than larger individuals (Webb and Kneib, 2004), which could explain the differences in shrimp growth rates between both coastal lagoons.

The minimum growth rate estimated for P. aztecus in Laguna Madre was below the lowest growth rate reported for this species by Knudsen et al. (1977) through a mark-recapture study in marsh ponds from Louisiana (3.7 to $5.9 \mathrm{~mm}$ TL per week). Moreover, the maximum growth rate calculated for $P$. aztecus in the present study was below the highest growth rate $(0.27 \mathrm{~mm}$ CL per day which corresponds to $8.41 \mathrm{~mm}$ TL per week, approximately) observed in small-mesh net enclosures deployed in Barataria Bay (Louisiana) by Rozas and Minello (2011). It is worth noting that these studies in Louisiana were carried out during spring (May-June) when temperatures are usually high. For instance, growth rate of brown shrimp in Barataria Bay was estimated at an average temperature of about $27^{\circ} \mathrm{C}$ (Rozas and Minello, 2011), whereas the present study in Laguna Madre was conducted throughout an annual cycle, with lower water temperatures $\left(14-21^{\circ} \mathrm{C}\right)$ during half of the year, particularly from November to March. Such differences in temperature could explain the 
above-mentioned results because higher growth rates are observed at higher temperatures (Dall et al., 1990).

Relationships with environmental conditions and body size

Growth rates of both shrimp species exhibited a significant linear relationship with water temperature, showing higher growth rates at higher temperatures (Fig. 4). Positive relationship between temperature and shrimp growth has also been reported in other field and laboratory studies (Zein-Eldin and Griffith, 1969; Staples and Heales, 1991; O’Brien, 1994; Perez-Castaneda and Defeo, 2005). In fact, when temperature increases, shorter intermoult periods are experienced by shrimp (Staples and Heales, 1991), which in turn lead to faster growth.

On the other hand, higher growth rates of both species were observed at salinities higher than $38 \%$. Such relationship was described by a quadratic function

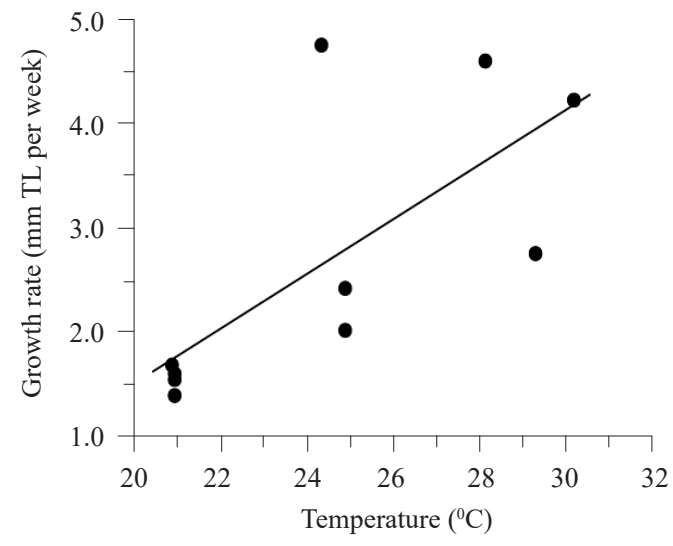

(a) (parabolic). However, in the case of $P$. duorarum the fitted model was not significant. It is worth noting that $P$. aztecus also registered a high growth rate at a salinity of $32.2 \%$ (Fig. 5). The fact that this species has shown higher growth rates at extreme salinities (higher and lower) in Laguna Madre is contrary to what has been observed in juvenile shrimps of Penaeus merguiensis de Man, 1888 under controlled laboratory conditions which exhibited higher growth rates at salinities from 30 to $35 \%$, decreasing towards high and low extremes (Staples and Heales, 1991).

It has been pointed out that the growth of P. aztecus is more strongly influenced by temperature than by salinity (Zein-Eldin and Griffith, 1969). It is worth mentioning that the elevated growth rate of $P$. aztecus observed at the lowest salinity (32.25\%) in Laguna Madre (Fig. 5) also corresponded to the period of highest water temperature $\left(30.17^{\circ} \mathrm{C}\right)$ in the lagoon; therefore, it is likely that

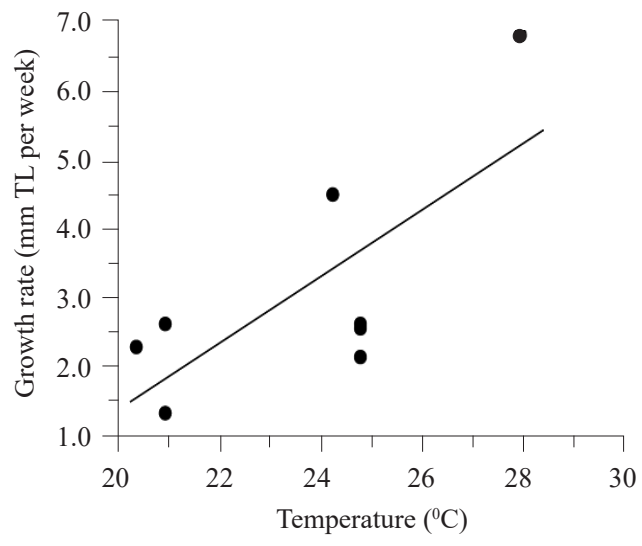

(b)

Fig. 4. Positive linear relationship between water temperature and growth rates of (a) P. aztecus and (b) P. duorarum from the Laguna Madre

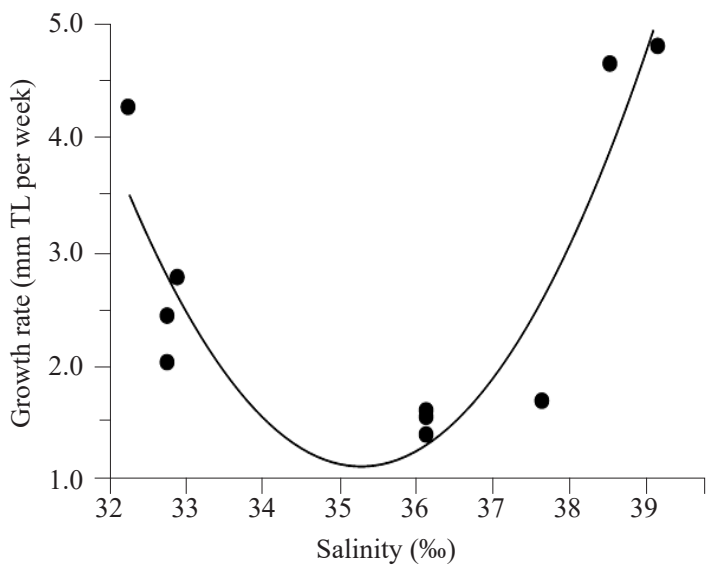

(a)

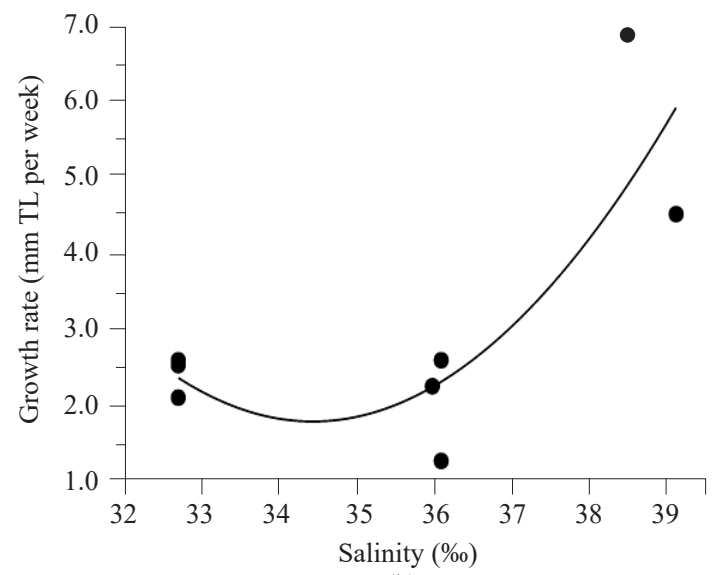

(b)

Fig. 5. Relationship between salinity and growth rates of (a) P. aztecus and (b) P. duorarum from Laguna Madre. In both cases a parabolic function was fitted 
this result may be due to the high water temperature, rather than the low salinity. Accordingly, it seems that temperature might be more important than salinity in determining changes in growth rates of penaeid shrimps in Laguna Madre. Similarly, growth rates of juvenile penaeid shrimps (P. brasiliensis, $P$. duorarum and $P$. notialis) in a tropical coastal lagoon from the Gulf of Mexico were mostly related to water temperature, although they were also influenced by the biomass of submerged aquatic vegetation (Perez-Castaneda and Defeo, 2005).

Finally, a negative linear relationship between growth rates and total length was observed in $P$. aztecus and $P$. duorarum in the present study (Fig. 6), indicating slower shrimp growth at larger sizes. Parameter estimates and corresponding statistics of the above fitted models are presented in Table 1. This coincides with results from a field tagging study of the banded coral shrimp Stenopus hispidus which showed a decrease in growth rate as shrimp body size increased (Chockley and St Mary,

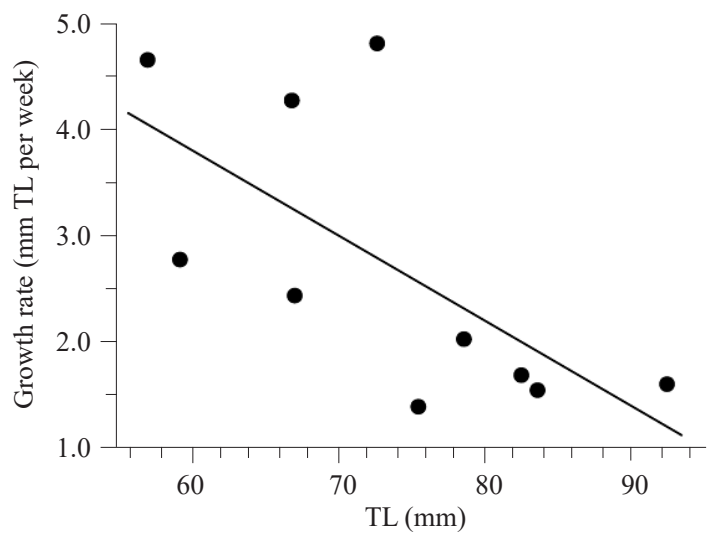

(a)
2003). Furthermore, other authors (Taylor et al., 2015) demonstrated that, under laboratory conditions, growth of the caridean shrimp Lysmata californica decreased with body size.

The length-based growth model for crustaceans over their life span can be represented, by an asymptotic curve as a function of age (time), as in many other aquatic animals (Caddy, 2003; King, 2007; Enberg et al., 2008; Chang et al., 2012). The growth curve for crustaceans, including penaeid shrimps, in terms of length denotes lower increments in length per unit time as the body length increases; in other words, growth rates decrease as individuals reach their maximum size. It is obvious that this trend can be more evident when the size range of the studied species is wide enough to include animals close to their maximum age/length (i.e., adults) and small individuals (i.e., juveniles). In the present study, growth rates of $P$. aztecus and $P$. duorarum were derived from individuals of juvenile to late subadult sizes, which

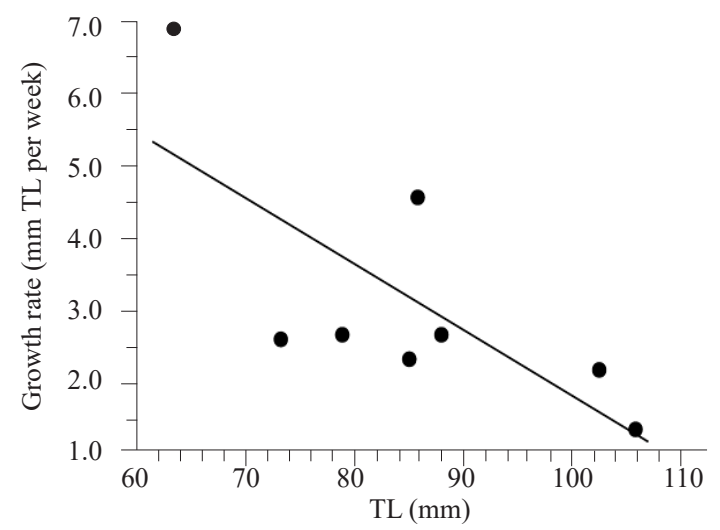

(b)

Fig. 6. Inverse linear relationship between body length and growth rates of (a) P. aztecus and (b) P. duorarum from Laguna Madre

Table 1. Parameter estimates $( \pm \mathrm{SE})$ and determination coefficients $\left(\mathrm{r}^{2}\right)$ corresponding to the fitted models that relate salinity, temperature and body size (independent variables) with growth rates (dependent variable) in P. aztecus and $P$. duorarum

\begin{tabular}{lllll}
\hline Species & & Temperature $\left({ }^{\circ} \mathrm{C}\right)$ & Salinity & Total length $(\mathrm{mm})$ \\
\cline { 2 - 4 } & & $\mathrm{y}=\mathrm{a}+\mathrm{bX}$ & $\mathrm{y}=\mathrm{a}+\mathrm{bX}+\mathrm{cX}$ & $\mathrm{y}=\mathrm{a}+\mathrm{bX}$ \\
\hline P. aztecus & $\mathrm{a}$ & $-3.89( \pm 2.28)$ & $334.88( \pm 60.13)^{* * *}$ & $8.67( \pm 2.39)^{* *}$ \\
& $\mathrm{~b}$ & $0.27( \pm 0.09)^{*}$ & $-18.93( \pm 3.40)^{* * *}$ & $-0.08( \pm 0.03)^{*}$ \\
& $\mathrm{c}$ & - & $0.27( \pm 0.05)^{* * *}$ & - \\
& $\mathrm{r}^{2}$ & 0.52 & 0.82 & 0.44 \\
\hline P. duorarum & $\mathrm{a}$ & $-8.31( \pm 4.41)$ & $230.68( \pm 121.01)$ & $10.96( \pm 3.04)^{*}$ \\
& $\mathrm{~b}$ & $0.48( \pm 0.19)^{*}$ & $-13.28( \pm 6.82)$ & $-0.09( \pm 0.04)^{*}$ \\
& $\mathrm{c}$ & - & $0.19( \pm 0.10)$ & - \\
& $\mathrm{r}^{2}$ & 0.53 & 0.67 & 0.53 \\
\hline
\end{tabular}

$* \mathrm{p}<0.05, * * \mathrm{p}<0.01, * * * \mathrm{p}<0.001$ 
allowed the detection of the negative relationship between growth rates and body size of shrimp.

In summary, results from this study suggest that under field conditions growth rates of $P$. aztecus and $P$. duorarum in Laguna Madre are positively influenced by water temperature but negatively related to the body size, which implies that the positive effect of water temperature on the increase in length of shrimp would be size-dependent.

\section{Acknowledgements}

This work was supported by FOMIX Tamaulipas under Grant TAMPS-2005-C08-08; RPC received an additional support from the Mexican Government (SEP) under Grant PFCE-2016-28MSU0010B-10. We thank Mr. Emeterio Dueñez Resendiz, from Carboneras fishing village, for his help during biological sampling in Laguna Madre.

\section{References}

Adnan, N. A., Loneragan, N. R. and Connolly, R. M. 2002. Variability of and the influence of environmental factors on the recruitment of postlarval and juvenile Penaeus merguiensis in the Matang mangroves of Malaysia. Mar. Biol., 141(2): 241-251. DOI: 10.1007/s00227-002-0837-2.

Alvarez, F. N., Gracia, A. G. and Soto, L. A. 1987. Growth and mortality of the estuarine phases of the pink shrimp Penaeus (Farfantepenaeus) duorarum Burkenroad, 1939 in Laguna de Terminos, Campeche, Mexico. An. Inst. Cienc. Mar Limnol., 14(2): 207-220 (In Spanish).

Benfield, M. C., Bosschie, J. R. and Forbes, A. T. 1990. Growth and emigration of Penaeus indicus H. Milne-Edwards (Crustacea, Decapoda, Penaeidae) in the St. Lucia Estuary, Southern Africa. Fish. Bull., 88(1): 21-28.

Bhattacharya, C. G. 1967. A simple method of resolution of a distribution into its Gaussian components. Biometrics, 23(1): 115-135. DOI: $10.2307 / 2528285$.

Blanco-Martinez, Z. and Perez-Castañeda, R. 2017. Does the relative value of submerged aquatic vegetation for penaeid shrimps vary with proximity to a tidal inlet? Preliminary evidence from a subtropical coastal lagoon. Mar. Freshw. Res., 68(3): 581-591.

Caddy, J. F. 2003. Scaling elapsed time: an alternative approach to modelling crustacean moulting schedules? Fish. Res., 63(1): 73-84. DOI: 10.1016/S0165-7836(02)00277-1.

Chang, Y. J., Sun, C. L., Chen, Y. and Yeh, S. Z. 2012. Modelling the growth of crustacean species. Rev. Fish Biol. Fish., 22(1): 157-187. DOI: 10.1007/s11160-011-9228-4.

Chockley, B. R. and St Mary, C. M. 2003. Effects of body size on growth, survivorship and reproduction in the banded coral shrimp, Stenopus hispidus. J. Crust. Biol., 23(4): 836-848. doi.org/10.1651/C-2392.
CONAPESCA 2013. Anuario estadístico de acuacultura y pesca 2013. Comision Nacional de Acuacultura y Pesca (CONAPESCA), Mazatlan, 295 pp.

Dall, W., Hill, B. J., Rothlisberg, P. C. and Sharples, D. J. 1990. The biology of the Penaeidae. In: Blaxter, J. H. S. and Southward, A. J. (Eds.), Advances in marine biology, vol. 27. Academic Press, London, 489 pp.

Enberg, K., Dunlop, E. S. and Jorgensen, C. 2008. Fish growth. In: Jorgense, S. E. and Fath, B. (Eds.), Encyclopedia of ecology. Elsevier, Amsterdam, p. 1564-1572.

FAO 2015. Global capture production 1950-2015. FAO fisheries statistics.http://www.fao.org/fishery/statistics/globalcapture-production/query/en (Accessed 12 December 2017).

Garcia, S. and Le Reste, L. 1981. Life cycles, dynamics, exploitation and management of coastal penaeid shrimp stocks. FAO fisheries technical paper 203. Food and Agriculture Organisation of the United Nations, Rome, $215 \mathrm{pp}$.

Gayanilo, F. C. and Pauly, D. 1997. FAO-ICLARM stock assessment tools (FISAT). Reference manual. FAO computerised information series. Fisheries No. 8. Food and Agriculture Organisation of the United Nations, Rome, $262 \mathrm{pp}$.

Gillett, R. 2008. Global study of shrimp fisheries. FAO fisheries technical paper 475. Food and Agriculture Organisation of the United Nations, Rome, $331 \mathrm{pp}$.

Haywood, M. D. E. and Staples, D. J. 1993. Field estimates of growth and mortality of juvenile banana prawns (Penaeus merguiensis). Mar. Biol., 116(3): 407-416. DOI: 10.1007/ BF00350057.

INP 2006. Sustainability and responsible fishing in Mexico. National Institute of Fisheries (INP), Mexico City, 544 pp. (In Spanish).

King, M. 2007. Fisheries biology, assessment and management. Blackwell, Oxford, 382 pp.

Knudsen, E. E., Herke, W. H. and Mackler, J. M. 1977. The growth rate of marked juvenile brown shrimp, Penaeus aztecus, in a semi-impounded Louisiana coastal marsh. In: Higman, J. B. (Ed.), Proceedings of the Gulf and Caribbean Fisheries Institute, $29^{\text {th }}$ annual session, 8-10 November 1976. Brownsville, Texas, p. 144-159.

Mace, M. M. and Rozas, L. P. 2017. Population dynamics and secondary production of juvenile white shrimp (Litopenaeus setiferus) along an estuarine salinity gradient. Fish. Bull., 115(1): 74-88. doi: 10.7755/FB.115.1.7.

Neal, R. A. and Maris, R. C. 1985. Fisheries biology of shrimps and shrimplike animals. In: Provenzano, A. J. (Ed.), The biology of crustacea, vol. 10. Academic Press, New York, $110 \mathrm{pp}$.

O'Brien, C. J. 1994. Population dynamics of juvenile tiger prawns Penaeus esculentus in south Queensland, Australia. Mar. Ecol. Prog. Ser., 104: 247-256. DOI: 10.3354/ 
meps 104247.

Perez-Castaneda, R. and Defeo, O. 2003. A reciprocal model for mortality at length in juvenile pink shrimps (Farfantepenaeus duorarum) in a coastal lagoon of Mexico. Fish. Res., 63(2): 283-287. DOI: 10.1016/S01657836(03)00058-4.

Perez-Castaneda, R. and Defeo, O. 2005. Growth and mortality of transient shrimp populations (Farfantepenaeus spp.) in a coastal lagoon of Mexico: role of the environment and density-dependence. ICES J. Mar. Sci., 62(1): 14-24. doi. org/10.1016/j.icesjms.2004.10.005.

Perez-Castaneda, R. and Defeo, O. 2004. Spatial distribution and structure along ecological gradients: penaeid shrimps in a tropical estuarine habitat of Mexico. Mar. Ecol. Prog. Ser., 273: 173-185. DOI: 10.3354/meps273173.

Perez-Castaneda, R., Robles-Hernandez, C. A. and SanchezMartinez, J. G. 2012. Interspecific variations in population structure of penaeids from an artisanal shrimp fishery in a hypersaline coastal lagoon of Mexico. J. Coast. Res., 28(1A): 187-192. doi.org/10.2112/JCOASTRES-D-11-00089.1.

Perez-Farfante, I. 1970. Diagnostic characters of juveniles of the shrimps Penaeus aztecus aztecus, $P$. duorarum duorarum and $P$. brasiliensis (Crustacea, Decapoda, Penaeidae). US Fish Wildlife Service, special scientific report No. 599. USFWS, Washington, p. 1-26.

Perez-Farfante, I. 1988. Illustrated key to Penaeoid shrimps of commerce in the Americas. NOAA technical report, National Marine Fisheries Service No. 64. National Oceanic and Atmospheric Administration, Washington, p. 1-32.

Ramirez-Rodriguez, M. and Arreguin-Sanchez, F. 2000. Growth of pink shrimp Farfantepenaeus duorarum (Burkenroad, 1939) in Campeche Sound, Mexico. Crustaceana, 73(10): 1263-1272. DOI: 10.1163/156854000505245.
Rozas, L. P. and Minello, T. J. 2011. Variation in penaeid shrimp growth rates along an estuarine salinity gradient: Implications for managing river diversions. J. Exp. Mar. Biol. Ecol., 397(2): 196-207. DOI: 10.1016/j.jembe.2010. 12.003 .

Ruas, V. M., Rodrigues, M. A., Dumont, L. F. C. and D'Incao, F. 2014. Habitat selection of the pink shrimp Farfantepenaeus paulensis and the blue crab Callinectes sapidus in an estuary in southern Brazil: influence of salinity and submerged seagrass meadows. Nauplius, 22(2): 113-125. doi.org/10.1590/S0104-64972014000200005.

Staples, D. J. and Heales, D. S. 1991. Temperature and salinity optima for growth and survival of juvenile banana prawns Penaeus merguiensis. J. Exp. Mar. Biol. Ecol., 154(2): 251-274. doi.org/10.1016/0022-0981(91)90168-V.

Taylor, J. R. A., Gilleard, J. M., Allen, M. C. and Deheyn, D. D. 2015. Effects of $\mathrm{CO}_{2}$-induced $\mathrm{pH}$ reduction on the exoskeleton structure and biophotonic properties of the shrimp Lysmata californica. Sci. Rep., 5: 10608.

Tunnel, J. W. and Judd, F. W. 2002. The Laguna Madre of Texas and Tamaulipas. Texas A\&M University Press, Corpus Christi, 372 pp.

Webb, S. and Kneib, R. T. 2004. Individual growth rates and movement of juvenile white shrimp (Litopenaeus setiferus) in a tidal marsh nursery. Fish. Bull., 102(2): 376-388.

Zein-Eldin, Z. P. and Griffith, G. W. 1969. An appraisal of the effects of salinity and temperature on growth and survival of postlarval penaeids. In: Mistakidis, M. N. (Ed.), Proceedings of the world scientific conference on the biology and culture of shrimps and prawns. FAO fisheries reports No. 57, vol. 3. 12-21 June 1967. Mexico City, Mexico, p. 1015-1026. 